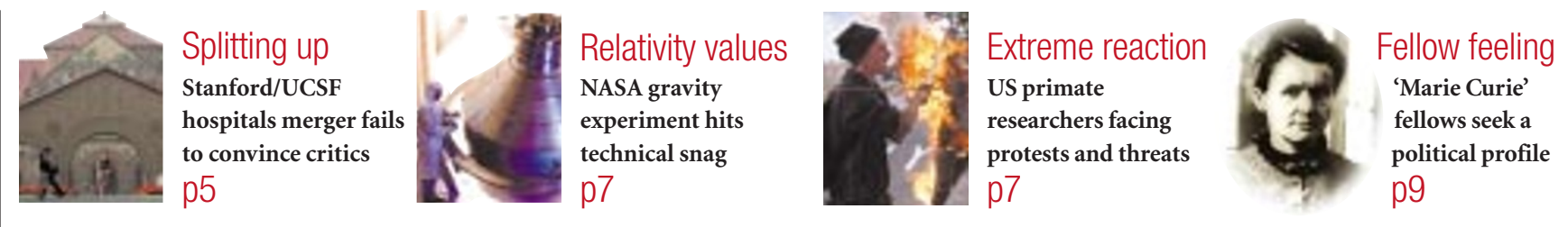

\title{
Life science facilities in crisis as Brussels switches off funding
}

Paris

Several major European life-science research facilities face financial crisis following the European Commission's decision not to fund their operational costs out of the fifth five-year Framework programme (FP5).

One facility directly affected is the European Bioinformatics Institute (EBI) in Cambridge, which forms Europe's main database infrastructure for molecular biology and biotechnology. An outstation of the European Molecular Biology Laboratory (EMBL), EBI has relied on the European Union for almost half its budget, but now finds that this tap has suddenly been switched off.

Other facilities affected are the recently created European Mouse Mutant Archive, based at Monterotondo near Rome (see next page), and the Drosophila stock centres at Umeå in Sweden and Szeged in Hungary.

Under instruction from member states, the European Commission published a new rule in March stating that core funding and operational costs for infrastructure should not qualify for support from FP5, which runs from 1998 to 2002. Member states wanted to control investment decisions on large science facilities themselves, and preferred such funding to be provided directly.

But EBI failed to recognize the rule's significance, especially since research infrastructure was made a priority in FP5, with funding rising from 200 million euros (US\$212 million) in the previous Framework programme to 500 million euros for this one. EBI had not read the small print specifying that such funds would be used only for research projects and to fund researchers from one country working at facilities in another.

Realization dawned over the summer, when the European Commission rejected EBI's applications for Framework funds. No one doubts the scientific excellence of EBI, says one commission official. "They were simply outside the scope of funding."

Embarrassed commission officials are now advising EBI on how to rewrite their proposals to include areas that will meet the new funding criteria. But one official admits that sleights of hand, such as dressing up

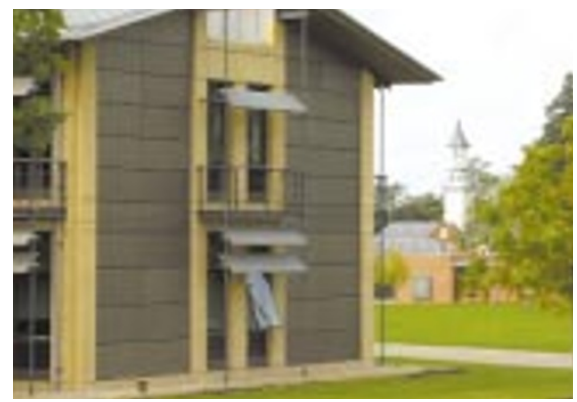

Hard times ahead? The European Bioinformatics Institute in Cambridge faces a funding problem.

infrastructure costs as research projects, are no longer an option. A spate of financial scandals prompted the commission to resign en masse earlier this year, and in the new squeaky-clean climate the commission is applying the rules to the letter.

As a result, funding for EBI from existing European Union contracts will dry up at the end of the year, and EBI accountants estimate that the shortfall will form 44 per cent of its budget. If the immediate cash-flow problem is not resolved, "we will have to abandon major projects like the DNA database, the draft human genome, the macromolecular structure database and the microarray expression database," warns Graham Cameron, who jointly heads the institute with Michael Ashburner, professor of biology at the University of Cambridge.

The crisis has come at a bad time for EBI. Demand for its services is growing at 15 per cent every month, while the Drosophila genome is likely to be available in February, with a draft of the human genome in the spring (see Nature 401, 729-730; 1999).

The need for EBI to expand is widely supported (see Correspondence, page 12). The institute and many in the community it serves believe its annual budget should be doubled from its current $\$ 8$ million if it is to remain competitive with its US equivalent, the National Center for Biotechnology Information, which has a budget of $\$ 19$ million.

The EMBL board will meet later this month to try to drum up money from its member states to tide EBI over until a permanent solution is found. Most observers are optimistic that the money will be found, as they argue that it would be unthinkable to let EBI sink.

"Everyone realizes that this is really a small amount of money for so many countries to put together to keep Europe competitive," says Julio Celis, chairman of the EMBL

\section{South Africa says AIDS drug 'toxic'}

\section{Cape Town}

South Africa's president Thabo Mbeki last week said the country would not take the "irresponsible" step of supplying AZT (zidovudine) to HIV and AIDS sufferers until the drug's safety was established.

The statement is being seen as an attempt to justify the government's tardiness in making AZT available in state hospitals, even to rape victims and pregnant women.

Mbeki claimed that legal cases were pending in South Africa, the United States and Britain against the use of AZT on the grounds that it was harmful.

But this has been strongly denied by Peter Moore, medical director for subSaharan Africa for Glaxo Wellcome, the drug's suppliers, who have requested a meeting with Mbeki to clarify the issue. The company has been negotiating with the government for the past three years over the price of supplying the drug to state hospitals.

Mbeki's statement was made in his first address to the National Council of Provinces since he became president in June. He argued that a large body of scientific literature claimed that AZT is so toxic as to be a health hazard. He had asked national health minister Manto Tshabala-Msimang to investigate this, but said that, until her investigation was complete, it would be irresponsible for the government to ignore researchers' warnings.

Michael Cherry 
council and head of the Danish Centre for Human Genome Research in Århus.

But one official at the European Molecular Biology Organization (EMBO) is more cautious: "Given the vagaries of European politics, I would not be overly optimistic that the member states will say, 'fine, let's pay up."

Since EBI was created in 1994, it has been funded five parts by EMBL, five parts by the European Commission and two parts by industry. But there is no alternative plan now that the commission has pulled out.

Fotis Kafatos, director of EMBO, says that

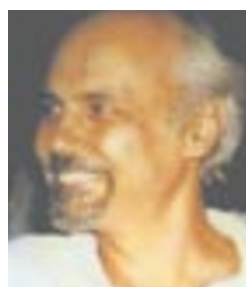

Kafatos: calls for more coordination. the fundamental issue is whether Europe will invest in essential structures for molecular biology and biotechnology, and that the challenge for European science is to $\mathrm{CO}^{-}$ ordinate national, multilateral and panEuropean systems.

"There is no clear mechanism for creating pan-European infrastructures that are globally competitive, because the funding is so fragmented," adds Cameron.

Commission officials say that, in principle, the treaties regulating the European
Union give it a clear mandate to plan and fund research infrastructure - the principle of subsidiarity says it should support activities that are best carried out at the European level rather than at the level of member states.

But the political reality is that member states are loath to give the commission such powers. The favoured model is one in which transnational initiatives are organized under multilateral accords between member states - the so-called 'variable geometry'.

According to one commission official, member states have been keen to keep decisions on big science facilities, such as the European Spallation Source and new synchrotrons, out of the commission's hands. Member states believe they are better at controlling budgets and accountability.

The challenge is to devise a mechanism for stable long-term funding to secure EBI's future as a globally competitive organization, says Ashburner. The United Kingdom is said to be ready to lead efforts to achieve this.

Britain is unlikely to contest the ruling against supporting EBI, as it was among the countries most against funding infrastructure directly, says a commission official.

Discussions are taking place on several levels. Britain's Medical Research Council is brokering discussions with other European research councils for a rescue plan, and is seeking support from governments.

The Wellcome Trust, which contributed half of the initial construction costs of EBI (see Nature 361, 383; 1993), is also being mentioned as a possible backer, although its support may depend on governments agreeing a long-term plan for EBI.

A meeting of the EMBL council in March will seek support for EBI from its member states. EMBL's current five-year plan for its programme and budget ends in December 2000 and, if a solution is to be found within EMBL, European member states will need to agree to a funding envelope for EBI in the next five-year plan.

"We need a long-term political commitment," says Ashburner. One option member states may consider is to fund EBI as a separate entity within a new multilateral accord.

Celis believes that the crisis has precipitated a long-overdue discussion on securing a stable and adequately funded structure for EBI and for other Europeanlevel facilities. Project funding is no way to run large infrastructure projects, he says. "What is needed is a mechanism involving stable partners, stable financing and longterm commitments.” Declan Butler

\section{Framework funding ban hits mouse mutant archive}

\section{Munich}

The financial crisis facing the European Bioinformatics Institute (see above) is also threatening the European Mouse Mutant Archive (EMMA). The archive, which has its main site at Monterotondo near Rome, has had its application for European Union (EU) infrastructure funding turned down.

The application was coordinated by Davor Solter, a director of the Max Planck Institute for Immunobiology in Freiburg, and a member of the programme committee that selects strains to be held at EMMA and its nodes in France, Britain and Sweden.

The funding request covered "basic activities required for acceptance of mutant strains, freezing of sperm and embryos, and molecular characterization of the strains".

EMMA was set up with grants totalling 3.9 million euros (US\$4.1 million) from the biotechnology infrastructure programme within the EU's fourth Framework programme (FP4), and with support from national organizations. It was created in response to the demand for mutant mice for the study of the function of sequenced genes.

Scientists and European Commission officials involved in negotiating EU grants in 1996 and 1997 expected continued funding in subsequent EU framework programmes.

But even then, EMMA scientists viewed the short-term nature of the funding as unsatisfactory for a facility that cannot be temporarily closed pending new grants. "You can't put the mice on a shelf and ask them to wait for the next grant before they get their next feed," says Solter.

Now that EU funding has dried up, this dissatisfaction has turned to panic. The FP4 funds ran out in spring this year, at around the time that EMMA officially opened (see Nature 398, 183; 1999). The archive is being temporarily funded by the Italian research council, the CNR, although it was nervous about funding building and running costs.

Solter did not realize that the wording of the programme on which he based his application, which excludes "support for the construction and operation of research infrastructures, as well as for the collection of data", meant that running costs were excluded. "I sort of assumed 'operation' was referring to water and electricity," he says.

Commission officials are encouraging EMMA, like EBI, to reapply for FP5 money for research projects, which they say is all that the infrastructure programme can cover. There is certainly plenty of money available: funding for infrastructure within the life-sciences programme of FP5 totals 60 million euros, of which 12 million euros was available for the first round, but only 5 million euros has been allocated.

But a more stable solution is also being

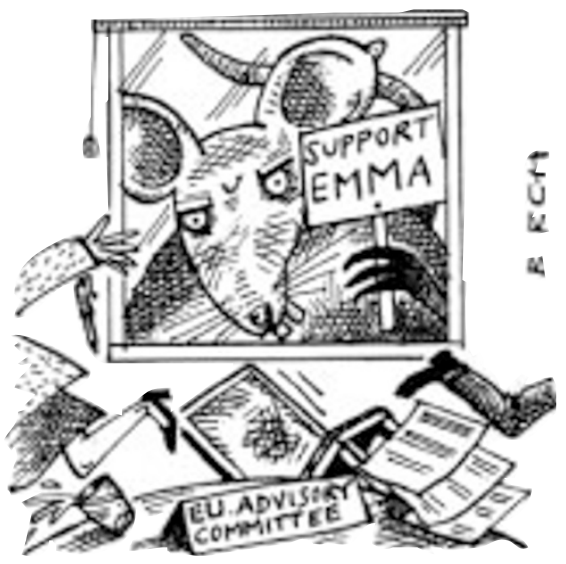

sought. "We need a constructive and timely alternative, such as a direct contribution from the European Union to operate EMMA," says Glauco Tocchini-Valentini, director of the CNR Institute of Cell Biology at Monterotondo, and CNR representative on EMMA's science-policy committee.

One commission official thinks that EMMA may be harder to rescue than EBI, which is well established and has multilateral support within EMBL. In contrast, he says, EMMA is covered by one national research council, and it may need member states to rally to its cause and create a new multilateral legal entity.
Alison Abbott 